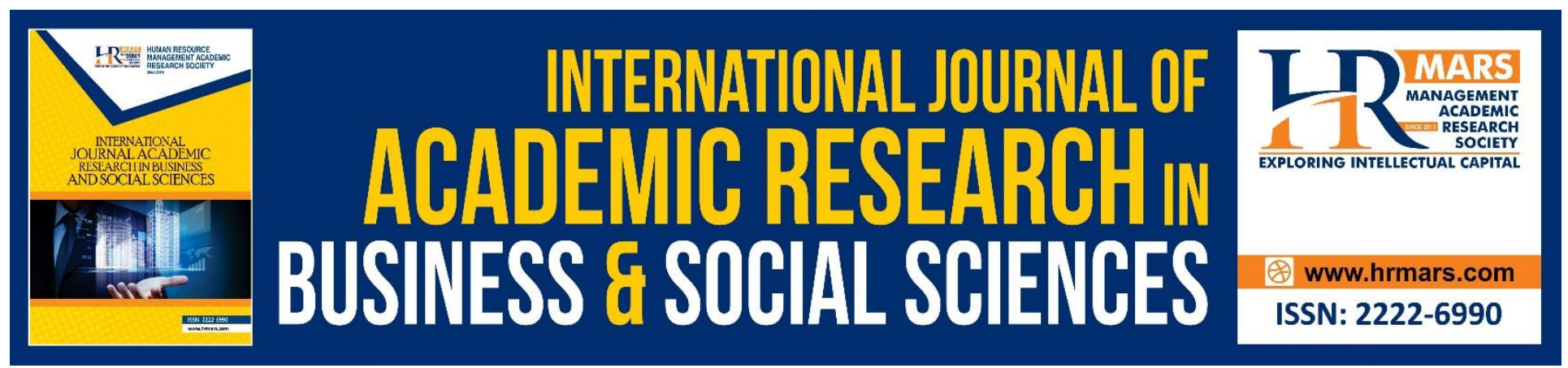

\title{
Forms of Al-ljarah Al-Muntahiyah bi Al-Tamlik and its Jurisprudential Adaptation
}

Rami Hussein, Kamarudin Awang Mat

To Link this Article: http://dx.doi.org/10.6007/IJARBSS/v9-i3/5715 DOI: $10.6007 /$ IJARBSS/v9-i3/5715

Received: 11 Feb 2019, Revised: 18 March 2019, Accepted: 27 March 2019

Published Online: 30 March 2019

In-Text Citation: (Hussein \& Mat, 2019)

To Cite this Article: Hussein, R., \& Mat, K. A. (2019). Forms of Al-ljarah Al-Muntahiyah bi Al-Tamlik and its Jurisprudential Adaptation. International Journal of Academic Research in Business and Social Sciences, 9(3), 546-554.

Copyright: @ 2019 The Author(s)

Published by Human Resource Management Academic Research Society (www.hrmars.com)

This article is published under the Creative Commons Attribution (CC BY 4.0) license. Anyone may reproduce, distribute, translate and create derivative works of this article (for both commercial and non-commercial purposes), subject to full attribution to the original publication and authors. The full terms of this license may be seen at: $\underline{\text { http://creativecommons.org/licences/by/4.0/legalcode }}$

Vol. 9, No. 3, 2019, Pg. 546 - 554

http://hrmars.com/index.php/pages/detail/IJARBSS

JOURNAL HOMEPAGE

Full Terms \& Conditions of access and use can be found at http://hrmars.com/index.php/pages/detail/publication-ethics 


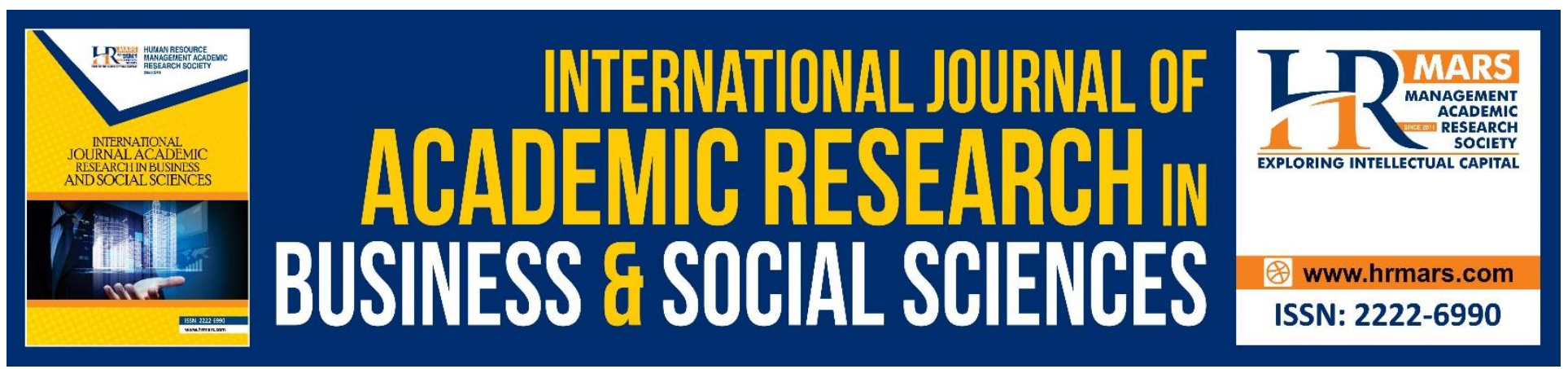

\title{
Forms of Al-ljarah Al-Muntahiyah bi Al-Tamlik and its Jurisprudential Adaptation
}

\author{
Rami Hussein, Kamarudin Awang Mat \\ Universiti Sultan Zainal Abidin
}

\begin{abstract}
Al-ljarah al-Muntahiyah bi al-Tamlik is a form of contract that is widely used in today's Islamic banking system. This paper discusses the forms of al-ljarah al-Muntahiyah bi al-Tamlik and its Jurisprudential adaptation as well as the steps of its application, its advantages and how to end this type of contract. Also, the most important findings of this study are discussed. This article uses the documentation method as a method of data collection and content analysis as a data analysis method. The findings shows al-ljarah al-Muntahiyah bi al-Tamlik contract is one of the most important contracts. It offers a lot of benefits for the basic needs of many people in the society. The contract also contributes to the economic development of Islamic banks and economic institutions that aim to develop their activities in relation to this type of contract.
\end{abstract}

Keywords: Ijarah, Adaptation, al-Tamlik

\section{Introduction}

It is a well-known fact that the trade has spread with expanded areas and its contracts have become complicated. In addition, the West has come up with various types of business contract which our scholars have not yet investigated either through research or fatwah (legal opinion). Also, the contemporary scholars have not agreed upon these types of business contract. To recognize the origin of these transactions, attention should be paid to their meaning. Nevertheless, these types of transaction have been presented in relation to Shariah (Islamic law) and attempted to prove things, such as some types of companies. Scholars have responded much to issues such as the benefits of banks and insurance while some aspects remain multifaceted, including al-ljarah al-Muntahiyah bi al-Tamlik, and the most important features of this type of contract are complexity and composition. There is disagreement amongst scholars on this type of contract in relation to its permissibility and prohibition. This study focuses on the meaning and forms of this type of contract, as well as its jurisprudential adaptation, advantages, steps and termination. 
INTERNATIONAL JOURNAL OF ACADEMIC RESEARCH IN BUSINESS AND SOCIAL SCIENCES

Vol. 9, No. 3, March, 2019, E-ISSN: 222 2-6990 @ 2019 HRMARS

\section{Definition of al-ljarah al-Muntahiyah bi al-Tamlik}

First: Legal definition of al-ljarah al-Muntahiyah bi al-Tamlik

al-ljarah al-Muntahiyah bi al-Tamlik defined as a contract intended for reconciliation between rent and sale. In this contract, the tenant is required to pay a higher amount than the regular rental value. After expiry of the period of contract, the tenant becomes the owner of the rented property (Badawi, 1989).

Al-Zuhaili (2002) believes that al-ljarah al-Muntahiyah bi al-Tamlik is: the ownership of benefit of certain objects such as goods and equipment for a certain period of time with a known fee that is usually higher than the normal rental value. In this contract, the ownership of the rented property shall be transferred to the tenant on the basis of a previous promise to own the property at the end or during the contract period after payment of all the rental dues or installments, by a new contract, that is to be owned by an independent contract, which is either a endowment or a sale. This could be done with a new contract, meaning that the ownership shall be completed under a different contract, either a endowment (hiba) or a sale (al-Zuhaili, 2002).

\section{Forms of al-ljarah al-Muntahiyah bi al-Tamlik and its Jurisprudential Adaptation}

The first form: Hire sale or rent associated with sale

This contract is one of the first forms of al-ljarah al-Muntahiyah bi al-Tamlik. It appeared in Britain in 1846 , and it is one of the most common forms of this contract, especially in commercial banks and non-Islamic financial institutions. Ownership of the rented property is transferred to the tenant after completing the rental payments. This this form of contract, the ownership of the rented property is automatically transferred from lessor to tenant without any new contract (al-Masri, 2002).

\section{Adaptation of this form of contract in Islamic Jurisprudence}

In order to properly adapt this type of contract, there is a need to consider the conditions that accompany it. It must be adopted if found suitable and rejected if unsuitable. Also, it is not possible to say that these conditions have transformed the contract from a lease contract into a sale contract. This is because the parties involved in the contract focus on a lease contract not a sale contract. Therefore, this type of contract is not the same as sale contract.

Can the contract be an unresolved sale where the installments paid by the tenant serves as the price? In this regard, the difference is that the installments are paid as a rent for the leased property. Therefore, how can these installments become the price for the leased property at the end of the period? Converting the price for the leased property in the subsequent contract does not conform to the rules which specify that each contract has its own provisions and effects.

Based on the above, it becomes clear that the ownership of the leased property is transferred to the tenant as soon as the last rent is automatically paid. This is done without a new contract or a price other than the amount paid as rental installments for the leased property during the specified period (Al-Shazali, 1988). 
Some scholars went on to find an alternative form of this type of contract, so that it becomes free from legal prohibitions. This form of contract is as follows: A sale contract is formulated, stipulating that the buyer has no any kind of comportment over the sold item (whether netting agreement or endowment) until all the payments are made, otherwise the contract is terminated. The payment of premiums shall be the installments paid for the rented property. The buyer takes control of the property after payment of all the installments, otherwise the seller takes possession of the property. Nevertheless, the installments paid during the previous period can managed by deducting the actual rental value from the installments paid during this period, in addition to compensation for damage suffered by the seller from such breach (Al-Shazali, 1988).

\section{The second form: al-ljarah al-Muntahiyah bi al-Tamlik through endowment}

This form of contract is applied by entering into a lease agreement with a promise from the lessor to donate the rented property after payment of all the installments (Ahmed, 2000).

\section{Legal adaptation of this form of contract}

According to the decision of the Islamic Jurisprudence Council, al-ljarah al-Muntahiyah bi al-Tamlik may be accompanied by promise of ownership either through endowment or sale. This decision stipulates that the promise of donating the assets at the end of the contract is permissible by a separate contract. It also provided for the transfer of ownership of the property to the lessee at the end of the contract period, in fulfillment of a previous promise to own the property (Qalah, 2007).

The third form: al-ljarah al-Muntahiyah bi al-Tamlik through gradual sale of the rented property In this form of contract, the parties agree to make successive and consecutive leasing contracts for the share owned by the lessor from the rented property at reach contract period. The tenant pays an amount of money equivalent to the portion at each rental period and pays another amount of money to buy shares or parts of the same rented property. This form of property is implemented by the Islamic Residential Cooperative Society in Toronto, Canada (Qahaf, 2000).

\section{Legal adaptation of this form of contract}

It is clear that this form of contract includes: agreement on the contract and on the gradual sale of the rented property. Therefore, the condition of this contract is the benefit of the property as well as the property itself by dividing such property into joint stocks. An amount is paid in addition to the payment of each rental installment for the purchase of a number of shares. The periodic installment shall consist of a fixed amount (specified in the contract) for all installments. Each installment consists of a cumulative share that corresponds to the original price of the rented property, as well as a diminishing share that corresponds to a calculated cost based on the amount of the remaining parts of the original price (Qahaf, 2000).

Based on the above, this contract is considered as a contract between sale and rent, provided that the sale is cumulative and the rent is diminishing for the same condition, and both sale and rent are related to the same property. 
The fourth form: al-Ijarah al-Muntahiyah bi al-Tamlik contract through sale after the payment of rental installments

This form of contract is different from the first form of contract as it consists of two contracts. The first is a rent contract and the second is a sale contract after the end of the contract period. Nevertheless, the first form consists of only one contract (Muhammad, 2004).

This form of contract has two conditions:

Condition 1: The price is symbolic.

Condition 2: The price is not symbolic.

In both cases, the price is predetermined, and the contract is not left to be determined by the market price at the time of conclusion of the contract (Qahaf, 2000).

\section{Legal adaptation of this form of contract}

The jurists of Constitutional Law considered this form of contract as a sale contract at a reduced price. Nevertheless, its adaptation to Islamic jurisprudence explicitly forbids it to be a lease contract. The provisions and effects of this contract during the period are intended for lease contract not sale contract. Its provisions and effects are only intended for a sale contract after the expiration of the period of lease contract as well as the obligations made by the contract, including the payment of all rental installments. Therefore, this contract can be formulated as an alternative to the other forms of contract explained, namely: a sale contract in which the tenant has no any kind of comportment over the property (whether netting agreement or endowment) until all the payments are made in the agreed manner (al-Saber, 1429H).

\section{The fifth form: al-ljarah al-Muntahiyah bi al-Takhyeer}

This is one of the common forms of the financial lease contract (Ahmed, 2000). The owner of the rented property sells the property to the tenant at a specified price on the basis of market price, or extension of the contract period to another period, or return of the rented property to its owner, meaning that the tenant has to choose between these three conditions. The contract can also be formulated as a lease contract, allowing the lessee to use the rented property for a specified payment in a known lease period. This is done with a binding promise made by the lessor to grand the tenant the right to three things upon completion of the contract period:

1. Extension of the contract period to another period.

2. Return of the rented property to the financial institution or its owner.

3. Ownership of the rented property at a price to be considered in determining the amounts previously paid (as rent installments). This price is specified at the beginning of the contract, or with market price upon completion of the contract (Al-Hafi, 1421H). 
INTERNATIONAL JOURNAL OF ACADEMIC RESEARCH IN BUSINESS AND SOCIAL SCIENCES

Vol. 9, No. 3, March, 2019, E-ISSN: 222 2-6990 ¿ 2019 HRMARS

\section{Legal adaptation of this form of contract}

This form of contract consists of adding a condition (option of purchase) to one of the forms of $\mathrm{Al}$ Ijarah Al-Muntahiyah Bi Al-Tamlik contract:

1. Al-ljarah al-Muntahiyah bi al-Tamlik by selling at a symbolic or non-symbolic price.

2. Al-ljarah al-Muntahiyah bi al-Tamlik through gradual sale.

3. Al-ljarah al-Muntahiyah bi al-Tamlik through endowment.

It is appropriate to discuss on the adaptation of each form of contract above. Each of these forms consists of purchase with an open condition placed by the lessor. The adaptation of the forms of contract with condition is not different form the adaptation of those without condition.

In other words, if the purchase option is added before the end of the lease period when the property is transferred to the lessee by selling at a symbolic price or by endowment, both forms are adjusted as installment sales. This adaptation does not change if the tenant uses his/her right to buy the rest of property based on the condition added to this form of contract, in which the property is transferred to the lessee when the gradual sale of the rented property is completed. Also, the adaptation of this form does not change. It is a cumulative sale and diminishing rent on the same property. The purpose of the purchase option is to hasten the procession of the property (by the tenant) and terminate of the contract by transferring the ownership to the tenant (Muhammad, 2004).

\section{The sixth form: ljaara Mubtadiah bi al-Tamlik}

This is a form of contract in which the property is told to the tenant at the beginning of the contract period with exclusion of the property from the sale for the contract period, and then the excluded sale benefits are sold to the same buyer of the property with a lease contract for the specified period (Qahaf, 2000).

\section{Legal adaptation of this form of contract}

This form of contract is considered as a complete sale under the condition that the sale benefits are excluded for a specified period of time (Muhammad) ${ }^{17}$.

\section{Steps for the Implementation of al-ljarah al-Muntahiyah bi al-Tamlik}

This contract is implemented according to the following steps (Al-Zuhaili, 2002).

1. The customer shows his/her desire to initiate the contract by requesting the material, such as machine or car.

2. The bank buys and own the material requested by the customer, receives the material and pays its owner.

3. It is possible that the Bank does not receive the machine or car, but the client is entrusted to receive it and notify the Bank about its suitability based on the required specifications.

4. The Bank rents out the machine or car to its customer at a particular amount for a specified period. Then, the Bank issues a promise to the customer to own the machine or car if all rental 
installments are paid, either by endowment or by selling at a symbolic or actual price agreed upon.

5. The Bank waives its ownership of the rented property, for example the machine or car, with a new contract upon expiry of the rent period. The tenant pays all the specified installments according to the promise, either endowment or sale, and then the ownership of the property is transferred to the tenant.

\section{Advantages of this Contract (al-Maghribi, 2013)}

Al-Ijarah al-Muntahiyah bi al-Tamlik contract has several advantages, such as:

It is flexible and easy to manage, and it allows both parties to revise (increase or decrease) the value of the rental installments at the end of the contract period and enter into a new period.

It is a legitimate contract according to sources of Fatwas (legal opinion in Islamic Law).

It allows the tenant to own the leased asset through obligation to pay rental installments, where he/she becomes a beneficiary of the property. The tenant is also assured to own the property by paying the last installment. The bank also retains the owner of the contracted property and does not waive the ownership whether by endowment or sale at a symbolic or actual price until all the installments agreed upon are paid by the tenant.

Termination of the Lease Contract: The contract ends with one of the following:

1. Damage of the rented property which results in loss of the intended benefit in the contract. For example, the contract ends if the car damages due to an accident and cannot be repaired to achieve the desired benefit (Legal Evidence Series for Islamic Banking, Islamic Guide to Leasing, 1998).

2. Expiry of the contract period: Islamic jurists have agreed that ljarah contract ends upon expiry of the specified period, and the tenant must return the property to the lessor (Shura Sharia Investment Company for Leasing, 2017).

3. Termination of the lease contract due to defect, which signifies deficiency in value and shows difference in price. The jurists have agreed that if there is a defect, the tenant has the options of either paying the rent or terminating the contract (Legal Evidence Series for Islamic Banking, Islamic Guide to Leasing, 1998).

4. Ijara contract ends with sale, and then a new lease contract may be initiated on different terms from the first contract (Al-Bashir, 2014).

5. According to Hanafi doctrine, ljarah contract also ends with the death of one of the parties, unlike other schools of thought (Al-Magribi, 2013).

\section{Findings}

Al-ljarah al-Muntahiyah bi al-Tamlik contract is one of the most important contracts which offers a lot of benefits for the basic needs of many people in the society. In addition, this contract contributes to the economic development of Islamic banks and economic institutions that aim to develop their activities in relation to this type of contract. 
INTERNATIONAL JOURNAL OF ACADEMIC RESEARCH IN BUSINESS AND SOCIAL SCIENCES

Vol. 9, No. 3, March, 2019, E-ISSN: 222 2-6990 ¿ 2019 HRMARS

The guarantee of the rented property during the contract period is given to the lessor and the tenant takes care of the property.

The lessor's responsibility is limited to necessary maintenance and repair in order to enable the lessee to benefit from the rented property. However, maintenance to obtain benefits and periodic maintenance are the tenant's responsibility.

\section{Corresponding Author}

Kamarudin Awang Mat, Faculty of Islamic Contemporary Studies, University Sultan Zainal Abidin Email:kamarudin@unisza.edu.my

\section{Acknowledgement}

Special thanks to Research Management, Innovation \& Commercialization Centre (RMIC) and University Sultan Zainal Abidin (UniSZA) for funding this research.

\section{References}

Badawi, A.Z. (1989). Dictionary of Legal Terminology. Cairo: Dar al-Kitab al-Misri. Beirut, Dar al-Kitab al-Libnani.

Ahmed, D.S. (2000). Al-tajeer al-Muntahi Bittamlik commercial financing tool acceptable in Sharia, 12th Session, Al-Riyadh Newspaper, Saudi Arabia, Economic Page, 30/9/2000, No: 11786

Al-Shazali, H. (1988). Al-Ijara Al-Muntahiya Bi Al-Tamlik, Magazine of Islamic Jurisprudence Academy, 5(4). pp 2639-2640).

Khairuldin, W. M. K. F. W. (2018). Fatwa Role in Education and Legal Dispute in Malaysia. International Journal of Academic Research in Progressive Education and Development, 7(4), 295-302.

Al-Hafi, K.A. (1412H). Ijarah Muntahiya Bittamlik in the light of Islamic Jurisprudence, second edition.

Al-Maghrabi, M.F. (2013). Between Theory and Practice, University of the Holy Quran and Islamic Sciences, Faculty of Administrative Sciences. Sudan, Khartoum.

Muhammad, M.Y. (2004). Al-ljarah al-Muntahiya bi al-Tamlik and Contemporary Applications of Ijarah Contract in Islamic Jurisprudence.

Khairuldin, W. M. K. F. W., Embong, A. H., Anas, W.N.I.W.N., Mohd, H. \& Ismail, D. (2018). The Application of Technology in the Dissemination of Fatwas: A Study on Religious Institutions in Malaysia, International Journal of Civil Engineering and Technology, 9(7), 2018, pp. 1590- 1596.

Khairuldin, W. M. K. F. W., Embong, A. H., Anas, W. N. I. W. N., Ismail, D., \& Mokhtar, W. K. A. W. (2019). An Augmented Reality (AR) Approach in Educational Integration of Du'a in Islam. Journal of Academic Research in Progressive Education and Development, 8(1), 32-39

Qala'a, M.R. (1428H). Contemporary Financial Transactions in Light of Jurisprudence and Sharia, Kuwait, Dar Al-Nafais Printing, 3rd Edition.

Al-Bashir, M. (2014). Problems of the Implementation of Al-Ijarah al-Muntahiya bi al-Tamlik and its Impact on Finance in Sudanese Commercial Banks. Master Thesis, Sudan University of Science and Technology, Graduate School.

Qahaf, M. (2000), ljarah Muntahiya Bi Al-tamlik and Sukuk al-Ayan al-Muajjarah. Research in the Islamic Jurisprudence Academy, Twelfth Session, Research Presented to the Islamic Jurisprudence Academy in Jeddah. 
Al-Masri, R. Y. (2008). A Scientific Review of the Book of Ijarah Muntahiya Bittamlik Contract, by Saad Al-Din bin Nasir Al-Shashri, Journal of King Abdulaziz University, Islamic Economics, No. 14, 20025 - Saad bin Abdullah al-Saber, leasing ended ownership, comparative jurisprudence Higher Institute of the judiciary.

Al-Zuhaili, W. (2002). Contemporary Financial Transactions - Research and Fatwas, Damascus, Syria, Dar al-Fikr, First Edition. 